\title{
The effects of bilateral septal lesions on two-way active avoidance in the guinea pig'
}

BRADLEY A. LOWN, WILLIAM N. HAYES, and RONALDE. SCHAUB, ${ }^{2}$ State University of New York at Buffalo, Buffalo, N.Y. 14214

Guinea pigs (Cavia porcellus) suffering bilateral septal destruction and sham operates were trained over a 2-day period in a two-way shuttle-box avoidance problem. Septal Ss reached the learning criterion more quickly, showed lower latencies, and displayed more intertrial activity than sham operates.

Evonic \& Brimer (1967) reported that guinea pigs, on a standard training schedule, are virtually unable tolearn a two-way active avoidance response. To explain this deficit, they suggest that in the guinea pig, fear responses may be "readily conditioned to any stable aspect of the avoidance situation," and that these fear reactions may produce "freezing behavior" which interferes with learning the task. Ireland, Hayes, \& Schaub (1969) have recently shown that bilateral hippocampal ablations bring about a dramatic improvement in the performance of guinea pigs in the two-way shuttlebox. These results are similar to those reported for rats (Green, Beatty, \& Schwartzbaum, 1967; Isaacson, Douglas, \& Moore, 1961; Olton \& Isaacson, 1968). Bilateral lesions of the septal area in rats have also been reported to reduce such freezing behavior (Schwartzbaum, Green, Beatty, \& Thompson, 1967) and to greatly facilitate learning of a two-way avoidance task (Schwartzbaum et al, 1967; Kenyon \& Krieckhaus, 1965; Krieckhaus et al, 1964). The purpose of the present study was to determine the effects of bilateral septal lesions on the freezing behavior and overall performance of guinea pigs in a two-way avoidance situation.

\section{METHOD}

The Ss were 12 experimentally naive, pigmented, male guinea pigs /Cavia porcel lus) weighing from $300-700 \mathrm{~g}$ at the time of surgery. Six received bilateral septal lesions and six served as sham operates. All surgery was performed with sodium pentobarbital anesthesia $(30 \mathrm{mg} / \mathrm{kg})$. Lesions were produced electrolytically by passing a 3-mA anodal dc current for $20 \mathrm{sec}$ through the uninsulated tip of a stainless-steel electrode that was placed stereotaxically into the brain. The stereotaxic coordinates varied somewhat according to the weight of the animal but the majority weighed from $400-600 \mathrm{~g}$ and the following coordinates were used: $13 \mathrm{~mm}$ anterior, $1 \mathrm{~mm}$ lateral to the midline, and $4 \mathrm{~mm}$ up from stereotaxic zero. Identical treatment was given to the sham operates except that no current was passed through the electrode. All lesions were verified histologically at the conclusion of the experiment by means of frozen-tissue technique and cresyl-violet stain. Representative reconstructions of the lesions are shown in Fig. 1.

The details of the shuttlebox used are given elsewhere (Ireland, Hayes, \& Schaub, 1969). The CS was the onset of a 100-W lightbulb and the US, a $1.0-\mathrm{mA}$ scrambled shock produced by a Model E6070B Grason-Stadler shock generator. The CS-US interval was $10 \mathrm{sec}$, and the intertrial intervals were 75,90 , or $105 \mathrm{sec}$, randomly varied. If no response was made, the US was terminated after $3 \mathrm{sec}$.

Testing began 1 week or more following surgery and consisted of two sessions in the shuttlebox. During the first session Ss were given 75 trials. The second session was given $48 \mathrm{~h}$ after the first and consisted of 50 trials. Each animal thus received a total of 125 trials. Events were controlled with conventional programming equipment, and escape responses, avoidance responses, spontaneous crosses, and response latencies were recorded. A learning criterion of nine avoidance responses in 10 trials was employed.

\section{RESULTS}

The number of trials necessary for each $\mathrm{S}$ to achieve the learning criterion is shown in Fig. 2. Ss with septal lesions clearly learned more rapidly than did the sham operates. A Mann-Whitney U test showed that septal Ss reached the criterion in significantly fewer trials than did the sham operated Ss $(\mathrm{p}<.01)$.

A Mann-Whitney $U$ test also revealed that the average response latencies of the septal Ss were significantly lower than those of the sham operated Ss $(p<.01)$ as shown in Fig. 3. The difference between the two groups in number of spontaneous crosses did not reach significance, although it approached it $(\mathrm{p}<.10)$.

Product-moment correlation coefficients were computed between number of spontaneous crosses per $S$ per block of 25 trials and average response latency per $S$ per block of 25 trials for each of the two groups. For normals and septals the correlations were

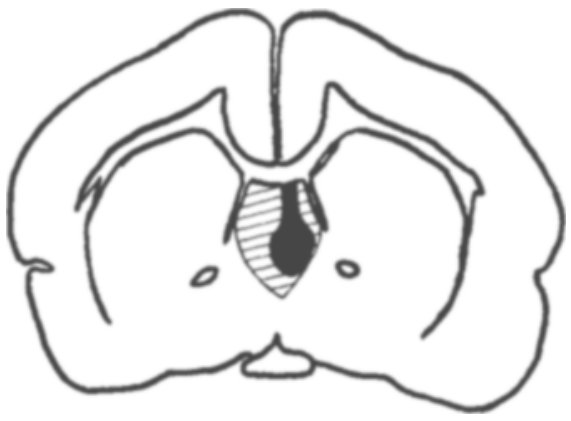

Fig. 1. Reconstructions of the maximum (striped area) and minimum (shaded area) damage sustained by septal Ss at one level of the lesion.

$-.82(\mathrm{p}<.10)$ and -.05 , respectively. This indicates that normal $S s$ which exhibit a high number of spontaneous crosses will also tend to exhibit low response latencies. This does not seem to be the case for the septal Ss, even though they exhibited more spontaneous crosses and lower response latencies than did the normals.

\section{DISCUSSION}

The results of the present experiment are in agreement with earlier work on rats (Schwartzbaum et al, 1967; Kenyon \& Krieckhaus, 1965; Krieckhaus et al, 1964) and hamsters (Matalka \& Bunnell, 1968). This earlier work and the present study clearly demonstrate a facilitatory effect of bilateral septal lesions on the performance of a two-way shuttlebox problem. The appearance of this phenomenon in the present study is particularly impressive, considering the normally poor performance displayed by guinea pigs on tasks of this nature (Evonic \& Brimer, 1967; Webster \& Rabedeau, 1964; Webster et al, 1965). Normal hamsters also display a deficit in learning a two-way avoidance task, although apparently not as great as that found with guinea pigs (Matalka \& Bunnell, 1968). It may be that this facilitation with septal lesions is a general phenomenon in rodents.

The present study also tends to support earlier work with rats reporting increased intertrial activity in septal Ss (Schwartzbaum et al, 1967). The increased intertrial

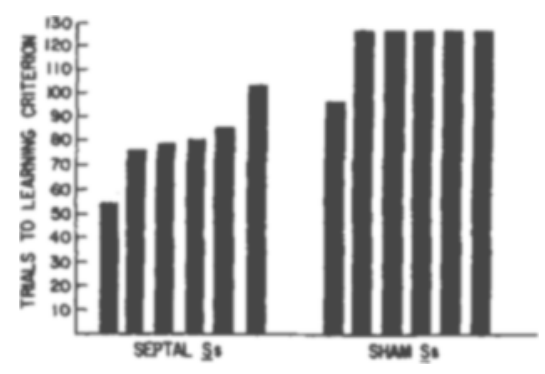

Fig. 2. Trials-to-learning criteria (nine avoidance responses in 10 trials) for both groups. 


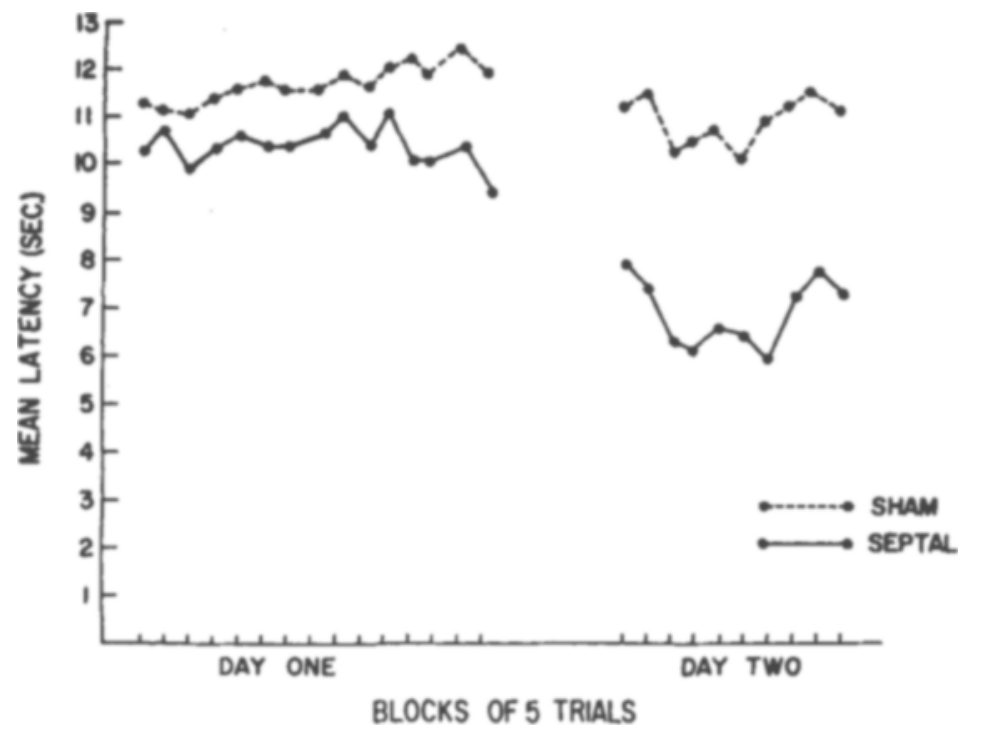

activity of the septal Sshas been regarded as an indication of a decrease in the freezing behavior normally displayed by guinea pigs on tasks of this nature. Previous work has shown, however, that increased intertrial activity is not necessary for the improvement of avoidance performance (Green \& Schwartzbaum, 1968). The extremely low correlation between response latency and frequency of spontaneous crossing found in the septal group of the present study lend further support to this hypothesis.

A recent study (Ireland et al, 1969) has reported similar effects to those reported here with hippocampal lesions in the guinea pig. These two studies on the guinea pig and earlier work with rats (Green et al, 1967) indicate a considerable overlap between the effects of these two types of lesions, the major effects being increased spontaneous activity, a facilitation of two-way active avoidance behavior, and reduction in freezing responses. It appears that, at least in rodents, septal and hippocampal lesions produce very similar effects in the shuttlebox task.

\section{REFERENCES}

EVONIC, I. N., \& BRIMER, C. J. Effect of variable temporal parameters in avoid ance conditioning of the guinea pig. Journal of Comparative \& Phy siological Psychology, 1967, 63, 536-538.

GREEN, R.H., BEATTY, W. W., \& SCHWARTZ-

BAUM, J. S. Comparative effects of septohippocampal and caudate lesions on avoidance behavior in rats. Journal of Comparative \& Physiological Psychology, 1967, 64, 444-452.

GREEN, R. H., \& SCHWARTZBAUM, J. S. Effects of unilateral septal lesions on avoidance behavior, discrimination reversal, and hippocampal EEG. Joumal of Comparative \& Phy siological Psychology, 1968, 65, 388-396.

IRELAND, L. C., HAYES, W. N., \& SCHAUB, R.

$E$. The effects of bilateral hippocampal lesions on two-way active avoidance in the guinea pig. Psychonomic Science, 1969, 14, 249-250.

ISAACSON, R. L., DOUGLAS, R. J., \& MOORE,
R. Y. The effect of radical hippocampal ablation on acquisition of avoid ance response. Joumal of Comparative \& Physiological Psychology, 1961, 54, 625-628.

KENYON, J., \& KRIECKHAUS, E. E. Enhanced avoidance behavior following septal lesions in the rat as a function of lesion size and spontaneous activity. Journal of Comparative \& Physiological Psychology, 1965, 59, 466-469. KRIECKHAUS, E. E., SIMMONS, H. J.,
MAX WHITE and SMITH MAYO, Druid Hills High School, and DAVID A. EDWARDS, Emory University, Atlanta, Ga. 30322

Adult female mice were tested for aggressive behavior against either immature and much smaller female mice or against relatively larger mature female mice. Female mice tested against much smaller females showed high levels of aggressive behavior.
Fig. 3. Mean response latencies for both groups for each day of training.

THOMAS, G. J., \& KENYON, J. Septal lesions enhance shock avoidance behavior in the rat. Experimental Neurology, 1964, 9, 107-113.

MATALKA, E. S., \& BUNNELL, B. N. Septal ablation and CAR acquisition in the golden hamster. Psychonomic Science, 1968, 12, 27-28.

OLTON, D. S., \& ISAACSON, R. L. Hippocampal lesions and active avoidance. Physiology \& Behavior, 1968, 3, 719-724.

SCHWARTZBAUM, I. S., GREEN, R. H., BEATTY, W. W., \& THOMPSON, J. B. Acquisition of avoidance behavior following septal lesions in the rat. Journal of Comparative \& Physiological Psychology, 1967, 63, 95-104.

WEBSTER, C. D., \& RABEDEAU, R. G. The effect of intersession interval in shuttle-box conditioning of the guinea pig. Psychonomic Science, 1964, 1, 73-74.

WEBSTER, C. D., BRIMER, C. J., \& EVONIC, I. Factors affecting intersession facilitation of avoidance learning in guinea pigs. Psychonomic Science, 1965, 3, 291-292. NOTES

1. This research was partially supported by Grant NB-05-001 from the National Institutes of Health.

2. Now at the University of Calgary, Alberta, Canada.

\section{Fighting in female mice as a function of the size of the opponent}

but females tested against other females of the same age and size showed little aggression. These results indicate that size of the opponent can be a potent determinant of the display of aggression in mice.

When two adult male mice that have been socially isolated are placed together, vigorous fighting usually occurs. Fighting in males is dependent upon testicular hor- 